Canadian Journal of Fisheries and Aquatic Sciences, Vol. 51, No. 9, 1994, pp.1993-2002. http://pubs.nrc-cnrc.gc.ca/eng/home.html

http://article.pubs.nrc-

cnrc.gc.ca/RPAS/RPViewDoc? handler_=HandleInitialGet\&calyLang=eng\&journal=cjf as\&volume $=51 \&$ articleFile $=$ f94-202.pdf

ISSN: $1205-7533$

DOI: $10.1139 / \mathrm{f} 94-202$

(C) National Research Council of Canada. 


\title{
Influence of Larval Gizzard Shad (Dorosoma cepedianum) Density on Piscivory and Growth of Young-of-Year Saugeye (Stizostedion vitreum $\times$ S. canadense)
}

\author{
Thomas P. Stahl and Roy A. Stein ${ }^{1}$ \\ Aquatic Ecology Laboratory, Department of Zoology, The Ohio State University, 1314 Kinnear Road, Columbus, OH 43212-1194, USA
}

Stahl, T.P., and R.A. Stein. 1994. Influence of larval gizzard shad (Dorosoma cepedianum) density on piscivory and growth of young-of-year saugeye (Stizostedion vitreum $\times$ S. canadense). Can. I. Fish. Aquat. Sci. 51: 1993-2002.

Growth and survival of young-of-year saugeye (Stizostedion vitreum $q \times S$. canadense $\delta$ ) (stocked into Ohio reservoirs to create sport fisheries) are probably influenced by prey availability, variations in which may account for historically documented variability in stocking success. Because saugeye switch from a diet of zooplankton to fish once stocked, we sought to determine experimentally if saugeye size and available ichthyoplankton, i.e., larval gizzard shad (Dorosoma cepedianum), affected this switch and whether piscivory improved saugeye growth. In an enclosure experiment, saugeye $(33.9 \mathrm{~mm} \mathrm{TL})$ immediately switched to piscivory when exposed to ichthyoplankton densities of 20 and $100 \cdot \mathrm{m}^{-3}$, growing faster when more gizzard shad were available. In another enclosure experiment, saugeye $30-49 \mathrm{~mm}$ TL consumed 14-mm gizzard shad. In ponds ( $N=4$ ponds-treatment ${ }^{-1}$ ) containing zooplankton and chironomids, we compared saugeye growth with and without larval gizzard shad and found, as in the first enclosure experiment, that piscivory improved saugeye growth. Neither saugeye size nor ichthyoplankton density influenced how quickly saugeye switched to piscivory. We conclude that managers should stock saugeye $\geq 30 \mathrm{~mm}$ 1-2 wk before peak ichthyoplankton densities to improve saugeye growth and survival by enhancing opportunities for exploitation of young-of-year gizzard shad.

La croissance et la survie de jeunes de l'année issus du croisement entre le doré jaune et le doré noir (Stizostedion vitreum $q \times S$. canadense $\delta$ ) (ensemencés dans des réservoirs en Ohio pour la pêche sportive) sont probablement influencées par l'abondance des proies, dont les variations peuvent expliquer la variabilité historique du succès de l'ensemencement. Étant donné que ce doré hybride passe d'un régime formé de zooplancton à un régime piscivore dès l'ensemencement, nous avons tenté de déterminer expérimentalement si la taille du poisson et la présence d'ichtyoplancton, c.-à-d. la larve de l'alose à gésier (Dorosoma cepedianum), influençaient cette modification du régime et si le régime piscivore accélérait la croissance du doré. Dans une expérience en enclos, les dorés $(\mathrm{LT}=33,9 \mathrm{~mm})$ ont adopté immédiatement un régime piscivore lorsqu'ils ont été exposés à des densités d'ichtyoplancton de 20 et de $100 \cdot \mathrm{m}^{-3}$, et leur croissance s'est révélée plus rapide en présence d'une plus grande quantité d'aloses à gésier. Dans une autre expérience en enclos, des dorés de 30 à $49 \mathrm{~mm}$ de LT ont consommé des aloses à gésier de $14 \mathrm{~mm}$. Dans des étangs $\left(N=4\right.$ étangs traitement $\left.{ }^{-1}\right)$ renfermant du zooplancton et des chironomides, nous avons comparé la croissance du doré avec et sans la présence d'aloses à gésier. Nous avons observé, comme dans la première expérience en enclos, que le régime piscivore activait la croissance des dorés. $\mathrm{Ni}$ la taille des dorés, ni la densité de l'ichtyoplancton n'influençaient la rapidité avec laquelle les dorés adoptaient le régime piscivore. Nous concluons qu'il faut introduire ce doré hybride lorsqu'il mesure $\geq 30 \mathrm{~mm}$ et 1 à 2 sem avant que la densité d'ichtyoplancton n'atteigne son maximum de manière à accélérer la croissance et la survie du doré en améliorant sa capacité d'exploiter les aloses à gésier de l'année.

Received August 31, 1993

Accepted March 16, 1994

$(J 12075)$
Reçu le 31 août 1993

Accepté le 16 mars 1994
So augeye (Stizostedion vitreum $q \times S$. canadense $\delta$ ) are predators stocked annually as young-of-year (YOY) into Ohio reservoirs to create and maintain sport fisheries. Survival of this hybrid varies dramatically among reservoirs and across years at the same reservoir (Stahl et al. 1992, 1993; M. Austin, Ohio Division of Wildlife, 1076 Old Springfield Pike, Box 576, Xenia, OH 45385, personal communication). In YOY fishes, growth strongly influences survival through the first growing season (Gutreuter and Anderson 1985; Miller et al. 1988; Madenjian and Carpenter 1991;

\footnotetext{
${ }^{1}$ Author to whom correspondence should be addressed.
}

Madenjian et al. 1991) and first winter (Oliver et al. 1979; Adams and DeAngelis 1987; Post and Evans 1989). Therefore, conversion to piscivory by YOY fishes may be particularly critical to success because feeding on fish increases condition, growth, and survival as compared with the use of other prey (Hokansen and Lien 1986; Wicker and Johnson 1987; Buijse and Houthuijzen 1992).

Percids reared in hatchery ponds are initially planktivorous, become benthivorous (Fox 1989; Fox et al. 1989; Culver et al. 1992; Madon and Culver 1993), and finally switch to piscivory if fish prey are available (Mathias and $\mathrm{Li} \mathrm{1982).} \mathrm{In}$ Ohio reservoirs, larval gizzard shad (Dorosoma cepedianum) 
are the primary prey (B.M. Johnson et al. 1988; Bremigan et al. 1991; Stahl et al. 1992) available to stocked saugeye. In fact, gizzard shad are preferred prey for many predators (Noble 1981; Carline et al. 1986; Matthews et al. 1988; Wahl and Stein 1988), including YOY saugeye (B.L. Johnson et al. 1988; B.M. Johnson et al. 1988; Stahl et al. 1992). Conceivably, high densities and preferred status of gizzard shad should permit rapid saugeye growth if they are stocked into systems with larval gizzard shad. However, saugeye often delay switching from planktivory and benthivory to piscivory once stocked (Stahl et al. 1992; Stahl 1993). This delay is unexpected given the benefit piscivory should convey.

One factor that could affect the switch from one prey type to another is prey density (Mittelbach 1981; Werner and Mittelbach 1981; Pyke 1984; Carline et al. 1986; Lyons 1987) - variations which could modify encounter rates between predators and their prey. As Mathias and Li (1982) have suggested for walleye and larval fish (i.e., ichthyoplankton), density likely also affects the time to switch for saugeye.

Another factor that may affect the switch to piscivory by saugeye is saugeye size in relation to gizzard shad size. Generally stocked into Ohio reservoirs at $30-50 \mathrm{~mm}$ (Stahl et al. 1992), saugeye (Lynch et al. 1982; B.L. Johnson et al. 1988) and walleye (Smith and Pycha 1960; Parsons 1971; Mathias and Li 1982; Jackson et al. 1992) are piscivorous at $\geq 39$ and $\geq 34 \mathrm{~mm}$, respectively, on fish $33-50 \%$ of their total length (Parsons 1971; Knight et al. 1984; B.M. Johnson et al. 1988). Therefore, some saugeye stocked into Ohio reservoirs may either be too small to switch to fish prey or they may not find sufficient prey fish of appropriate size.

Once an age-0 fish becomes piscivorous, its growth and survival are dictated by the availability of age-0 forage fishes (Smith and Pycha 1960; Forney 1976; Carlander and Payne 1977; Adams et al. 1982; Carline et al. 1986; Persson and Greenberg 1990). In Ohio reservoirs, larval gizzard shad densities at the time of saugeye stocking are positively related to saugeye weight in the fall and percent survival through the fall (Stahl 1993). Initial ichthyoplankton availability when stocked may be important for saugeye growth and survival, just as initial zooplankton availability when larval walleye first feed is important to survival ( $\mathrm{Li}$ and Mathias 1982). Madenjian et al. (1991) used prey abundance immediately after stocking as a basis for walleye growth in a modelling exercise. Jester (1971) and Momot et al. (1977) documented poor walleye recruitment when fish prey were unavailable at the time when walleye switched to piscivory. By mediating the time it takes for saugeye to become piscivorous and thus affecting growth after the switch, variable ichthyoplankton (i.e., larval gizzard shad) densities in Ohio reservoirs (Bremigan et al. 1991; Stahl et al. 1992) could be a key factor influencing saugeye success.

Because ichthyoplankton density may affect the switch to piscivory as well as growth after the switch, we sought to determine how gizzard shad density affects saugeye growth and the time required for saugeye to switch to piscivory. We also investigated whether saugeye size at stocking affects their ability to consume gizzard shad (i.e., become piscivorous). Finally, we determined if saugeye grow faster when piscivorous, as compared with planktivorous and benthivorous. If we understand how ichthyoplankton density affects saugeye survival, then we can manage stocking time and/or saugeye size to take advantage of the abundance of fish prey to improve growth and reduce mortality.

\section{Materials and Methods}

\section{Shad Density and the Saugeye Switch to Piscivory}

We conducted all experiments at the Hebron State Fish Hatchery (Licking County, Ohio) during spring 1992. To determine if gizzard shad density influences saugeye growth and the timing of the switch to piscivory, we designed a bag experiment that consisted of two treatments, low $\left(20 \cdot \mathrm{m}^{-3}\right)$ and high $\left(100 \cdot \mathrm{m}^{-3}\right)$ gizzard shad density $(N=8$ replicates. treatment $\left.^{-1}\right)$. Gizzard shad treatment densities were based on minimum and maximum peak ichthyoplankton densities in Ohio reservoirs stocked with YOY saugeye (Stahl et al. 1992; see Dettmers and Stein 1992 for sampling method). Experimental units were 4 -mil clear plastic bags $(107 \times$ $76 \times 178 \mathrm{~cm})$ stapled onto wooden frames associated with a walkway constructed in a hatchery pond. To sample gizzard shad and saugeye, bags were dismantled through time. We required 64 bags for eight replicates and four dismantling dates.

On 24 May 1992, experimental bags were filled with $\sim 1 \mathrm{~m}^{3}$ of water, most of which was filtered through a 54- $\mu \mathrm{m}-$ mesh net. Near the end of bag filling, the filter was removed and some zooplankton was added at densities lower than high ambient pond densities, yet still greater than reservoir densities, to ensure that piscivory was not artificially induced by a deficient alternate prey source. Bags were randomly assigned treatment and dismantling dates. That night, gizzard shad larvae $(20 \pm 2$ and $100 \pm 20$, low and high densities, respectively) were added to bags. Gizzard shad were $14.1 \pm 0.2 \mathrm{~mm} \mathrm{TL}$ (mean $\pm 1 \mathrm{SE}, N=130$ ), about $40 \%$ of saugeye body length. On the following morning, six saugeye $(33.9 \pm 0.2 \mathrm{~mm} \mathrm{TL}, 0.252 \pm 0.005 \mathrm{~g}, N=63)$ were added to each bag (day 0 ). Preliminary experiments indicated that handling mortality for gizzard shad and saugeye stocked into bags was negligible and that upon dismantling we could recover all gizzard shad added to bags (Stahl 1993).

Water temperatures inside bags were $16.5-23^{\circ} \mathrm{C}$; dissolved oxygen surface to bottom ranged from 7.8 to $16.6 \mathrm{mg} \cdot \mathrm{L}^{-1}$ and was measured with a YSI meter. On day 1 and immediately before the bags were dismantled, zooplankton were sampled from each bag with a clear Lexan tube sampler $(7.3 \mathrm{~cm}$ inside diameter, $1.6 \mathrm{~mm}$ thick; see DeVries and Stein 1991) and preserved in $70 \%$ EtOH. One sample consisted of two 1-m water columns taken from the bag with the tube sampler and sieve through a 54- $\mu \mathrm{m}$-mesh net. Bags were dismantled on days $2,4,8$, and 12 to collect saugeye and gizzard shad. During dismantling, we pumped all but about $15 \mathrm{~L}$ of water from the bag with a hose covered by a $500-\mu m-m e s h$ net to prevent fish loss. When only a few litres of water remained in the bag, we passed a hand net through the water until three successive efforts yieided no fish. Water could not be poured out of the bag due to bulkiness and the possibility of losing fish in folds. Saugeye were preserved on wet ice; gizzard shad were preserved in $95 \%$ EtOH. The experiment ended on 6 June 1992 after 12 d.

For zooplankton sample analysis, cladocerans were identified to genus and copepods were identified as calanoids, cyclopoids, or nauplii. Rotifers were not counted. For abundant taxa, a minimum of 50 individuals per sample was 
counted from a thoroughly mixed subsample. For rare taxa, counting proceeded until either 50 individuals or the entire sample was counted, if the extrapolated number of individuals in each taxon was $>25 \cdot$ sample $^{-1}$ after one eighth of the sample was counted. If the calculated number was $<25$, the estimated abundance and density of that taxon were based on the number counted in the initial one eighth of the sample. Up to 22 individuals of each taxon were measured (nearest $0.001 \mathrm{~mm}$ ) from the anterior margin of the head to the base of either the tail spine of cladocerans or the caudal rami of copepods using a digitizing board. Numbers were converted to density estimates (number per litre).

Gizzard shad from each bag were counted and measured (nearest $0.01 \mathrm{~mm}$ ). All saugeye were measured (nearest $0.5 \mathrm{~mm}$ ) and weighed wet (nearest $0.001 \mathrm{~g}$ ). Before the saugeye were weighed, their stomach contents were removed, identified, counted, and measured as per the zooplankton samples. Prey length was converted individually to biomass from length - dry weight regressions (zooplankton from Dumont et al. 1975; macrobenthic organisms from G. Mittelbach, Kellogg Biological Station, Michigan State University, Hickory Corners, MI 49060, unpublished data) to estimate biomass per saugeye (grams per gram). Due to digestion, gizzard shad from guts could not be measured; their dry weights were generated from initial mean lengths. Dry weights of saugeye were obtained from the following independent regression equation: dry weight $=$ $-0.018+0.21$. wet weight $\left(r^{2}=0.97\right.$, length range 25-91 mm, $N=319$ ).

All bags $(N=3)$ with $<4$ saugeye at dismantling were not used in analyses. Those bags with more gizzard shad than stocked, within error, also were discarded $(N=3)$. These discrepancies were the result of either stocking error or bags with holes. With these exclusions, replication was 6-8 bags treatment ${ }^{-1}$.dismantling date ${ }^{-1}$; for saugeye responses, the mean of 4-6 remaining saugeye per bag was a replicate in analyses. Because bags were independent through time due to dismantling, two-way ANOVAs (gizzard shad density $\times$ dismantling date) were used to analyze response variables.

\section{Saugeye Size and the Switch to Piscivory}

To judge the competency of saugeye to consume larval gizzard shad, we combined eight sizes (30-32, 32.5-33.5, $34.5-35.5,36.5-37.5,38.5-39.5,41-42,43-44$, and $45-49 \mathrm{~mm} \mathrm{TL})$ of saugeye with gizzard shad (14.1 $\pm 0.2 \mathrm{~mm}$ TL). On the evening of 23 May 1992, plastic buckets (22 L, $0.28 \mathrm{~m}$ diameter $\times 0.36 \mathrm{~m}$ height) were filled with $10 \mathrm{~L}$ of hatchery-pond water filtered through 54- $\mu \mathrm{m}$ mesh. Saugeye were collected from a hatchery pond, anesthetized with quinaldine, and measured (nearest $0.5 \mathrm{~mm}$ ). Five saugeye of a single size class were added to each bucket $(N=3$ replicates.size class ${ }^{-1}$ ). About $24 \mathrm{~h}$ later, gizzard shad were collected, counted $(15 \pm 2)$, and added by 23:00 to each bucket with $6 \mathrm{~L}$ more of water containing pond zooplankton. Saugeye were allowed to forage overnight and, at 10:00 the next morning, we collected the saugeye and preserved them on wet ice for stomach analysis. Gizzard shad were collected and preserved in $95 \% \mathrm{EtOH}$. At collection, the water temperature was $15^{\circ} \mathrm{C}$.

\section{Piscivory and Saugeye Growth}

To determine if piscivory increases saugeye growth, we generated two treatments, each with four replicate ponds
(0.4 ha, $0.5-1.5 \mathrm{~m}$ depth). One treatment contained zooplankton and chironomid larvae as prey; the other contained these prey plus larval gizzard shad.

Ponds were filled on 4 May 1992 and 60 adult gizzard shad, collected from Buckeye Lake (Licking-Fairfield counties, Ohio) on 7 May 1992, were randomly added to each of four ponds. On 21 May 1992 (day 0), once adult shad had spawned, we added about 20000 saugeye (33.1 \pm $0.2 \mathrm{~mm}$ TL, $0.216 \pm 0.004 \mathrm{~g}, N=62$ ) to each pond. Gizzard shad were $7.69 \pm 0.12 \mathrm{~mm}$ TL $(N=200) 1 \mathrm{~d}$ before the experiment began. Saugeye were stocked into experimental ponds in the same manner as they are stocked into reservoirs. After the rearing ponds were drained, saugeye were moved to indoor troughs, where the number in a $227-\mathrm{g}$ sample was counted. All saugeye were then bulk weighed, evenly divided among eight lots by weight, trucked to each pond, and stocked.

Zooplankton and larval gizzard shad were sampled every other day starting $1 \mathrm{~d}$ before saugeye stocking. Zooplankton were sampled at the deep end of each pond with a tube sampler (see previous description) and preserved in $70 \%$ EtOH. One sample consisted of three $1.5-\mathrm{m}$ water columns taken from the pond with the tube sampler and sieved through a 54- $\mu \mathrm{m}$-mesh net. Larval gizzard shad were preserved in 95\% EtOH after being collected by hand-hauling at the water's surface a $0.5-\mathrm{m}$-diameter, $500-\mu \mathrm{m}$-mesh net in open water over half the length of the pond. The net was equipped with a flowmeter mounted in its mouth to provide estimates of water volume filtered. Starting the day after saugeye were stocked, at least 10 saugeye were collected every other day before 10:00. Saugeye were collected from each pond within $1 \mathrm{~h}$ with a $4.6 \times 1.8 \mathrm{~m}$ seine $(3.2-\mathrm{mm}$ mesh) and preserved on wet ice. All ponds were drained on 1 June 1992. Saugeye were collected, transported to indoor troughs, and numbers estimated as described previously. At least 30 saugeye from each pond were measured (nearest millimetre) and weighed (nearest $0.001 \mathrm{~g}$ ). To compare larval gizzard shad densities between ponds with and without saugeye, on days 7 and 10 of our experiment we sampled a pond stocked with an equal number of adult gizzard shad at the same time as our experimental ponds.

We analyzed zooplankton and saugeye as described in the bag experiment, with the exception that on each sample date, $\geq 10$ saugeye per pond were measured (nearest $0.5 \mathrm{~mm}$ ) and weighed wet without stomach contents (nearest $0.001 \mathrm{~g}$ ), and the stomach contents of three fish per pond were analyzed. For saugeye response variables, the mean of all saugeye analyzed per pond per sampling date was a replicate. in analyses. Ichthyoplankton sample analysis consisted of counting a minimum of 200 individuals $\cdot$ sample $^{-1}$ from a thoroughly mixed subsample. Fifty individuals per sample were measured (nearest $0.01 \mathrm{~mm}$ ). Because ponds were sampled through time, repeated measures ANOVAs (gizzard shad presence $\times$ sampling date) were used to analyze response variables.

\section{Results}

\section{Shad Density and the Saugeye Switch to Piscivory (Bag Experiment)}

Whether a difference existed between original gizzard shad densities and densities on the first sampling day (day 2) was used as a qualitative metric for determining if saugeye 


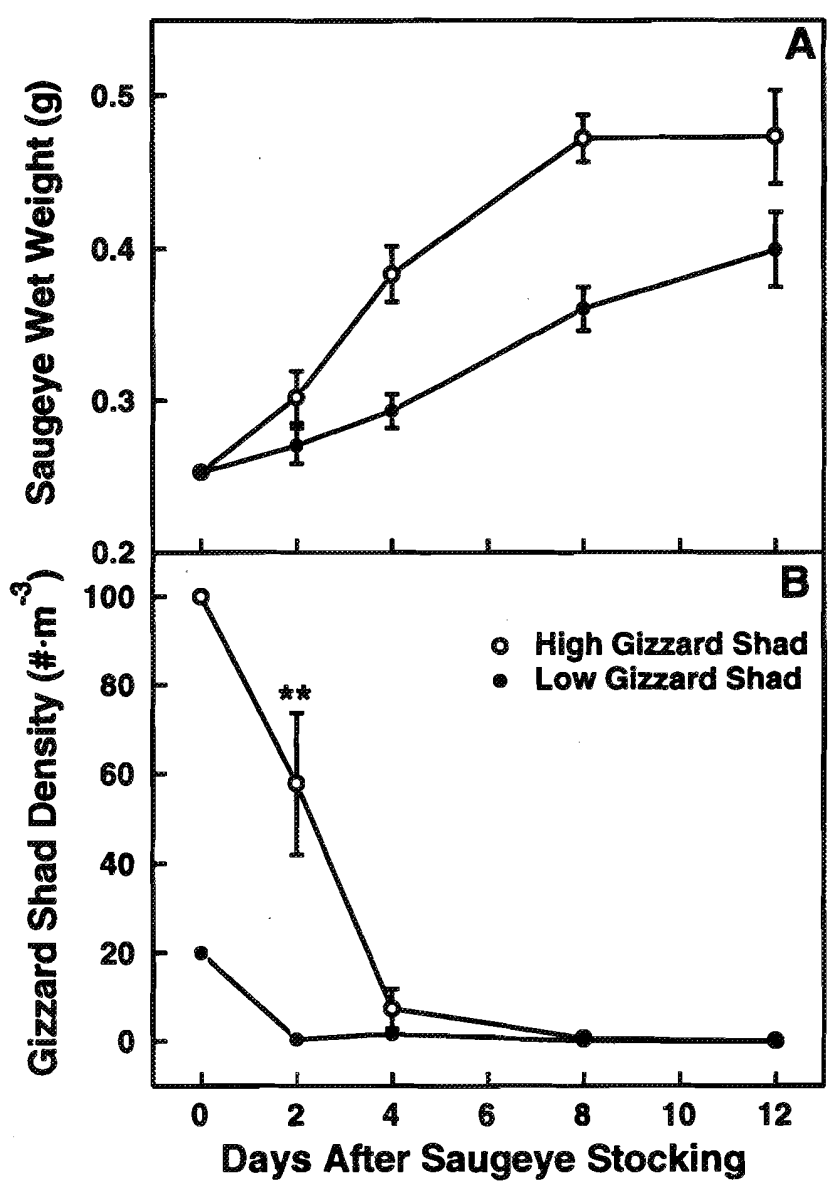

FIG. 1. (A) Mean $( \pm 1$ SE) saugeye wet weight through time $(N=6-8$, with 4-6 saugeye analyzed for each replicate) for the bag experiment done in 1992 at the Hebron State Fish Hatchery. Through time, saugeye wet weight increased faster in bags with high gizzard shad density (see Table 1 ). (B) Mean ( \pm 1 SE) gizzard shad densities through time $(N=6-8)$. Densities on day 0 represent gizzard shad stocked. Treatment differences ( $t$-tests, $\alpha_{\mathrm{adj}}=0.0125$ ) within a date are indicated by asterisks.

switched to fish prey in individual bags. This measure was used because recovery of gizzard shad from bags was $100 \%$, and gizzard shad were absent from saugeye guts in most low-density treatment bags on the first sampling day. Gizzard shad were missing from bags in both treatments on day 2 ; in turn, frequency of bags with gizzard shad absent did not differ between treatments (Pearson chi-square, $p=0.584$ ). Thus, treatments did not differ in switch time; saugeye were piscivorous by day 2 .

Although saugeye in both densities grew (Fig. 1A) as gizzard shad densities declined (Fig. 1B), those in enclosures with 100 gizzard shad.m $\mathrm{m}^{-3}$ grew larger than those with $20 \cdot \mathrm{m}^{-3}$ (Table 1 ). Neither consumption point estimates of zooplankton nor chironomids (grams prey dry weight per gram saugeye dry weight) differed between treatments (Fig. 2; Table 1). Saugeye consumed gizzard shad in both treatments through day 4 (Fig. 2). However, more gizzard shad and total prey were consumed by saugeye in the high than in the low gizzard shad density treatment (Table 1). Because an interaction effect existed between treatment and dismantling day (i.e., time, see Table 1), differences in gizzard shad and total prey consumed between treatments within a single date were tested with an adjusted experimentwise $\alpha$ of $0.05 / S\left(S=\right.$ number of comparisons, $\left.\alpha_{\mathrm{adj}}=0.0125\right)$ to determine when saugeye consumed more prey in the high gizzard shad treatment. Gizzard shad and total prey consumed were greater in the $100 \cdot \mathrm{m}^{-3}$ gizzard shad treatment on day 2 ( $t$-tests, $p<0.001)$. In the $20 \cdot \mathrm{m}^{-3}$ gizzard shad treatment (Fig. 2B), saugeye diet was primarily zooplankton; few gizzard shad were consumed on days 2 and 4 because few remained in bags (Fig. 1B).

Zooplankton was abundant in both treatments. Densities in bags ranged from 800 to $2300 \cdot \mathrm{L}^{-1}$ across treatments on all dates, except for bags with high gizzard shad densities on day 8 , when the density was only $338 \cdot \mathrm{L}^{-1}$. Zooplankton density did not differ between treatments at initial sampling on day 1 ( $t$-test, $p=0.87$ ) or through time on dismantling days (Table 1). Bosmina spp. were the major zooplankter; treatment means for percent Bosmina spp. on each sample day ranged from 97.4 to $99.9 \%$.

Gizzard shad densities in bags differed through time (Fig. 1B; Table 1). Due to an interaction effect (see Table 1), differences in gizzard shad density between treatments within a single date were also tested with an adjusted experimentwise $\alpha$ to determine when gizzard shad were more available in the $100 \cdot \mathrm{m}^{-3}$ gizzard shad treatment. Gizzard shad densities were only greater in the $100 \cdot \mathrm{m}^{-3}$ gizzard shad treatment on day 2 ( $t$-test, $p=0.004)$. Densities declined dramatically through days 2 and 4 in low and high gizzard shad bags, respectively. Both low and high gizzard shad densities fell to $0 \cdot \mathrm{m}^{-3}$ on days 8 and 12 , respectively.

Cumulative gizzard shad consumption was positively related to change in saugeye wet weight (Fig. 3). Eliminating all data except for days after which saugeye had consumed mostly gizzard shad improved this relationship (Fig. 3).

\section{Saugeye Size and the Switch to Piscivory (Bucket Experiment)}

After $11 \mathrm{~h}$ of saugeye foraging, an average of $0-5.3$ of the original 15 gizzard shad remained in each bucket. Number of shad consumed by different saugeye size classes did not differ (one-way ANOVA, $p=0.184$ ). Stomach analysis of saugeye from buckets also revealed that all size classes of saugeye had consumed gizzard shad.

\section{Piscivory and Saugeye Growth (Pond Experiment)}

We ended the pond experiment on day 11 because larval gizzard shad could not be sampled with our ichthyoplankton net. Gizzard shad were not evading our net because we were able to sample them in a pond without saugeye (see Fig. 4) that had been stocked with adult shad simultaneously with our experimental ponds. No larval gizzard shad were recovered when ponds with saugeye were drained.

Saugeye grew larger in ponds with gizzard shad (Fig. 4A; Table 1) and gizzard shad densities declined concomitantly (Fig. 4B). Although saugeye survived better in ponds without gizzard shad ( $t$-test, $p=0.021)$, the difference was small $(97.0$ versus $99.9 \%)$.

Gizzard shad did not occur in guts of sampled saugeye. Only zooplankton and macrobenthic organisms (i.e., chironomid larvae) occurred in saugeye stomachs (Fig. 5). Consumption point estimates (grams per gram dry weight) of zooplankton, chironomids, or total prey did not differ between treatments (Table 1). Because we could not explain saugeye 


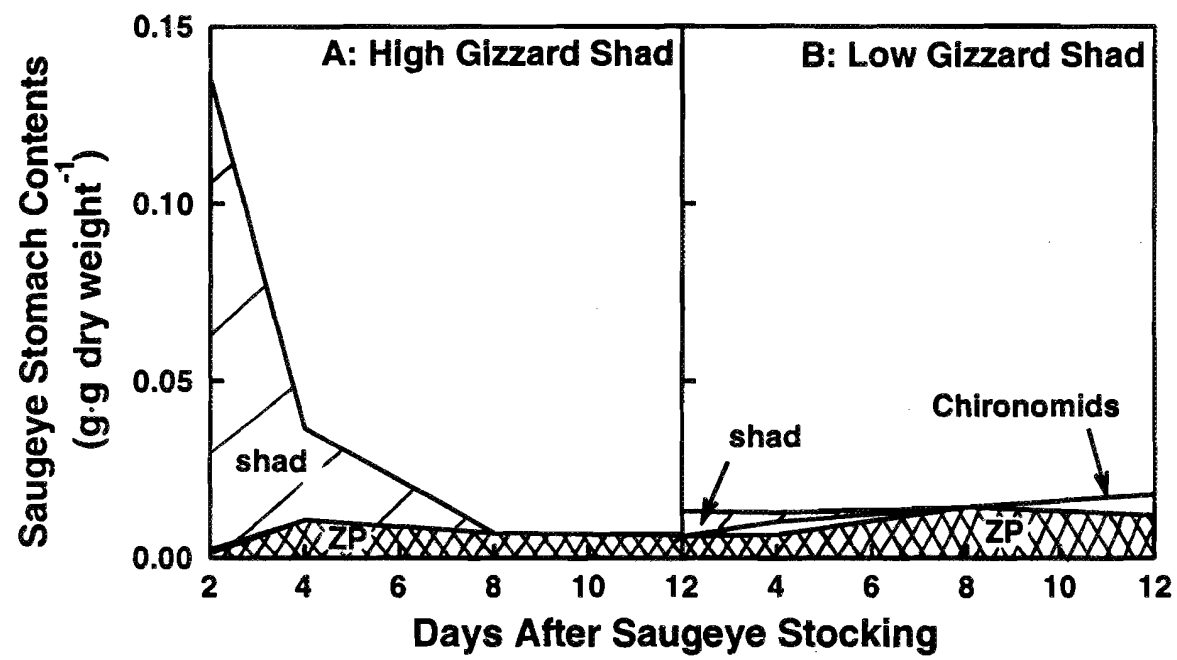

FIG. 2. Cumulative saugeye stomach contents in bags with (A) high and (B) low gizzard shad densities through time ( $N=6-8$, with 4-6 saugeye analyzed for each replicate) for the bag experiment done in 1992 at the Hebron State Fish Hatchery. Gizzard shad and total gut contents were greater with high gizzard shad (see Table 1); within dates, differences existed on day 2 for these measures $\left(t\right.$-tests, $\left.\alpha_{\text {adj }}=0.0125\right)$. $\mathrm{ZP}=$ zooplankton.

TABLE 1. Significance levels ( $p$-values) from statistical comparisons for the bag (two-way ANOVA) and pond (repeated measures ANOVA) experiments completed at the Hebron State Fish Hatchery in 1992. Response variables with units in parentheses are given for each experiment. $N$ represents number of replicates treatment ${ }^{-1}$. dismantling/sampling day ${ }^{-1}$. If saugeye were used for a response, number of saugeye-replicate ${ }^{-1}$ is indicated in parentheses. In sources of effects, treatment is gizzard shad availability, time is dismantling (bag) or sampling (pond) day, and interaction is between treatment and time. Significant treatment and interaction effects are indicated by an asterisk; refer to text and figures for direction of significant changes.

\begin{tabular}{|c|c|c|c|c|c|}
\hline \multirow[b]{2}{*}{ Experiment } & \multirow[b]{2}{*}{ Response variable } & \multirow[b]{2}{*}{$N$} & \multicolumn{3}{|c|}{ Source } \\
\hline & & & Treatment & Time & Interaction \\
\hline \multirow[t]{7}{*}{ Bag } & Saugeye wet weight $(\mathrm{g})$ & $6-8(4-6)$ & $<0.001 *$ & $<0.001$ & 0.255 \\
\hline & $\begin{array}{l}\text { Zooplankton } \\
\text { Zo }\end{array}$ & $(4-0)$ & 0.133 & 0.153 & 0.258 \\
\hline & Chironomid & & 0.062 & 0.217 & 0.109 \\
\hline & Gizzard shad & & $<0.001^{*}$ & $<0.001$ & $<0.001 *$ \\
\hline & Total prey & & $<0.001^{*}$ & $<0.001$ & $<0.001 *$ \\
\hline & Zooplankton density $\left(\right.$ no. $\left.\cdot \mathrm{L}^{-1}\right)$ & $6-8$ & 0.915 & 0.021 & 0.353 \\
\hline & Gizzard shad density (no. $\cdot \mathrm{m}^{-3}$ ) & $6-8$ & $<0.001 *$ & $<0.001$ & $<0.001 *$ \\
\hline \multirow[t]{7}{*}{ Pond } & Saugeye wet weight $(\mathrm{g})$ & $4(\geq 10)$ & $<0.001 *$ & $<0.001$ & 0.523 \\
\hline & Saugeye stomach contents $\left(\mathrm{g} \cdot \mathrm{g}^{-1}\right)$ & $4(3)$ & & & \\
\hline & Zooplankton & & 0.701 & $<0.001$ & 0.378 \\
\hline & Chironomid & & 0.204 & 0.006 & 0.931 \\
\hline & Total prey & & 0.187 & 0.002 & 0.948 \\
\hline & Zooplankton density $\left(\right.$ no. $\left.\cdot \mathrm{L}^{-1}\right)$ & 4 & $0.025^{*}$ & 0.002 & 0.761 \\
\hline & Gizzard shad density $\left(\right.$ no. $\left.\cdot \mathrm{m}^{-3}\right)$ & 4 & $<0.001 *$ & $<0.001$ & $<0.001^{*}$ \\
\hline
\end{tabular}

weight differences on the basis of observed prey consumption, we examined prey availability and electivity to determine where differences existed between treatments.

Mean total zooplankton density per pond per date ranged from 467 to $14793 \cdot \mathrm{L}^{-1}$ during the experiment; densities were lower in gizzard shad ponds (Table 1). As in the bag experiment, Bosmina spp. were most numerous and comprised at least $84 \%$ of the zooplankton density after day 0 . Calanoid, cyclopoid, nauplius, and Daphnia spp. densities were unaffected by gizzard shad (repeated measures ANOVA, for all treatment effects: $p>0.05$ ).

Saugeye electivity (Chesson's alpha: Chesson 1978, 1983) differed among zooplankton taxa (calanoids, cyclopoids, nauplii, Daphnia spp., Bosmina spp., and other cladocerans) in both treatments. Saugeye generally preferred cyclopoids and Daphnia spp., showed neutral electivity for calanoids, and avoided nauplii, Bosmina spp., and other cladocerans. Saugeye electivity between treatments for individual taxa on each sampling day did not differ ( $t$-tests, $\alpha_{\mathrm{adj}}=0.01$.

Gizzard shad densities in ponds differed through time (Fig. 4B; Table 1). Due to an interaction effect (see Table 1), differences in gizzard shad density between treatments within a single date were tested with an adjusted experimentwise $\alpha$ of $0.05 / S$ ( $S=$ number of comparisons, $\alpha_{\text {adj }}=0.008$ ) to determine when gizzard shad densities were no longer greater 


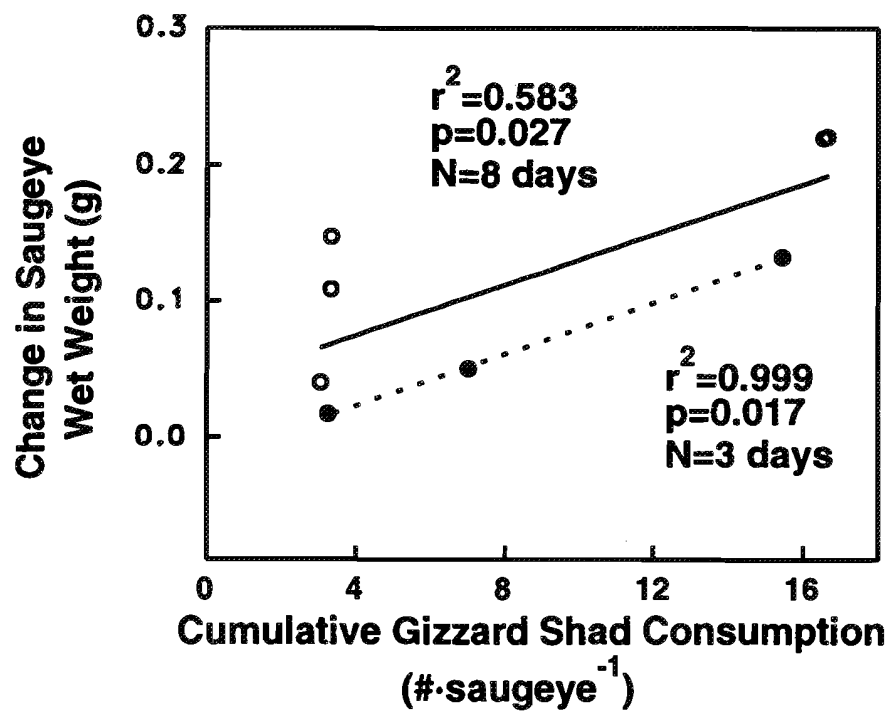

FIG. 3. Change in saugeye wet weight versus cumulative gizzard shad consumption (determined from gizzard shad bag counts) for the bag experiment done in 1992 at the Hebron State Fish Hatchery $(N=8$, four dismantling dates $\times$ two treatments). The solid line is a regression for all data points; the broken line is a regression for only the solid circles. Solid circle data points represent dismantling days after which saugeye had consumed mostly gizzard shad.

in the treatment with gizzard shad. Gizzard shad densities were only greater in the gizzard shad treatment on day -1 , before saugeye were stocked (Fig. 4B; $t$-test, $p=0.001$ ). Gizzard shad densities declined dramatically from $71.2 \cdot \mathrm{m}^{-3}$ $1 \mathrm{~d}$ before saugeye were stocked to $<3 \cdot \mathrm{m}^{-3} 1 \mathrm{~d}$ after stocking. After day 2 , when densities were $<1 \cdot \mathrm{m}^{-3}$, gizzard shad could still be sampled in a pond without saugeye (Fig. 4B), suggesting that gizzard shad did not evade our ichthyoplankton net.

\section{Discussion}

\section{Factors Affecting the Switch to Piscivory}

Neither saugeye size nor larval gizzard shad density affected the time required for saugeye to become piscivorous. Saugeye, as well as walleye (Parsons 1971; Knight et al. 1984; B.M. Johnson et al. 1988), can consume fish 33-50\% of their total length. In our experiments, saugeye $30-49 \mathrm{~mm}$ consumed $14-\mathrm{mm}$ gizzard shad $(29-47 \%$ of saugeye TL). Also, 30-mm saugeye, smaller than those percids dealt with in other studies (34-mm walleye, Mathias and Li 1982; 39-mm saugeye, B.L. Johnson et al. 1988), were piscivorous. Although saugeye $<30 \mathrm{~mm}$ were not tested, these fish likely can consume gizzard shad as well. YOY saugeye of the size stocked into Ohio reservoirs can consume fish.

The time for saugeye to switch to piscivory did not differ between bags containing 20 and 100 gizzard shad $\cdot \mathrm{m}^{-3}$. At both densities, saugeye consumed gizzard shad within $48 \mathrm{~h}$; it is likely that the switch to gizzard shad occurred shortly after saugeye were added to bags, based on our bucket experiment results. Gizzard shad densities $\geq 20 \cdot \mathrm{m}^{-3}$ did not reduce the time required to switch.

Although saugeye switched to piscivory within $48 \mathrm{~h}$ in our experiments, they do not switch this quickly when stocked into reservoirs at similar sizes (Stahl et al. 1992;

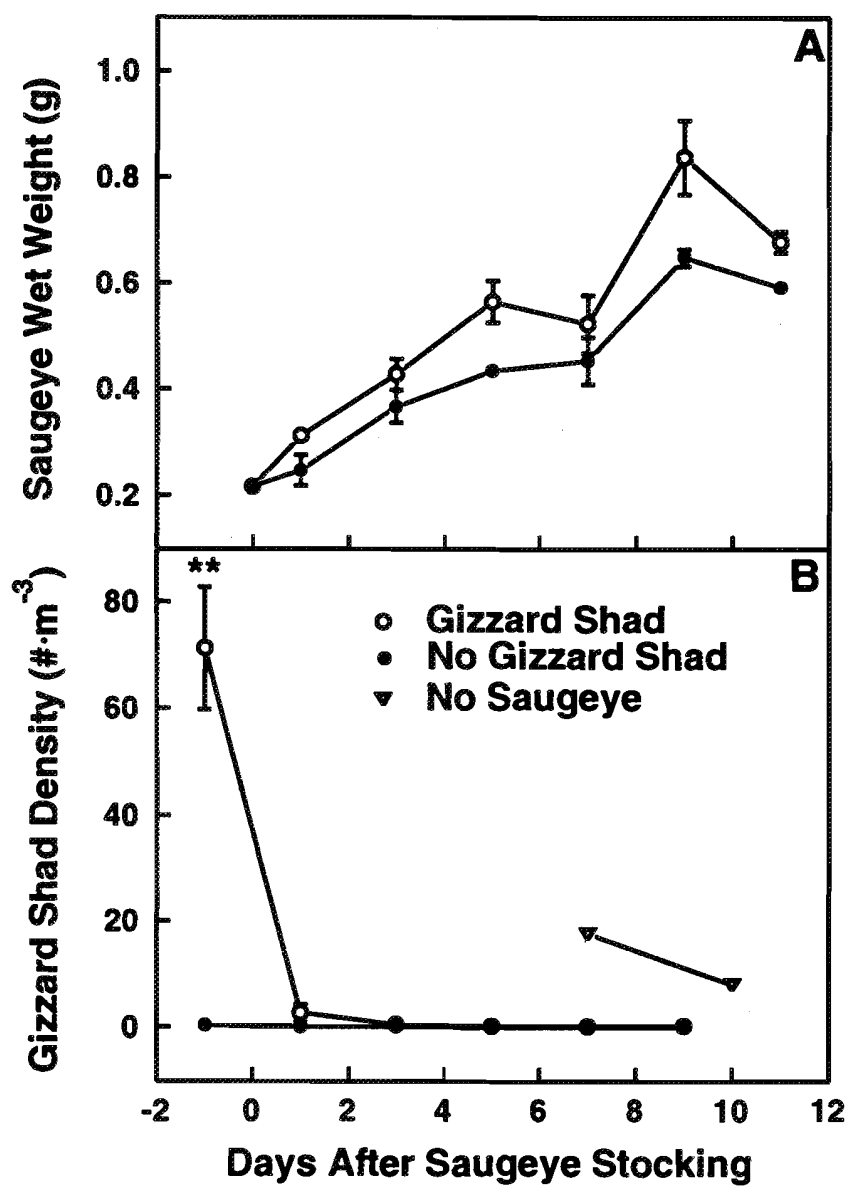

FIG. 4. (A) Mean ( \pm 1 SE) saugeye wet weight through time ( $N=4$ ponds, with at least 10 saugeye weighed per pond) for the pond experiment done in 1992 at the Hebron State Fish Hatchery. Through time, saugeye wet weight increased faster in ponds with gizzard shad (see Table 1). (B) Mean ( \pm 1 SE) gizzard shad densities through time ( $N=4$ ponds). Triangular data points are from a pond without saugeye, stocked simultaneously with the experimental ponds with an equal number of adult gizzard shad. Treatment differences ( $t$-tests, $\alpha_{\text {adj }}=0.008$ ) within a date are indicated by asterisks.

Stahl 1993). Conceivably, larval gizzard shad densities $<20 \cdot \mathrm{m}^{-3}$ could inhibit the switch to piscivory by either being below an optimal gizzard shad density in relation to other prey or falling below a density where saugeye learn to consume a novel prey item. In our experiments, saugeye drove gizzard shad densities to zero; thus, this predator can exploit low prey densities and would likely switch to piscivory at low gizzard shad densities. However, high gizzard shad densities may be required for saugeye to switch to piscivory initially; once a single gizzard shad is captured, then saugeye may continue to consume shad. Saugeye exposed to low densities initially will experience a reduced encounter rate, which might deter pursuit because of added search time. Coupling low densities of gizzard shad with shorter dismantling times in another bag experiment would provide insight into required threshold densities for the switch to fish prey.

One factor other than ichthyoplankton density that may cause a delayed switch to piscivory by saugeye is an abundant, alternate preferred prey. Large zooplankton have been mentioned as important for walleye growth and survival (Fox et al. 1989; Fielder 1992) and might be sufficiently 


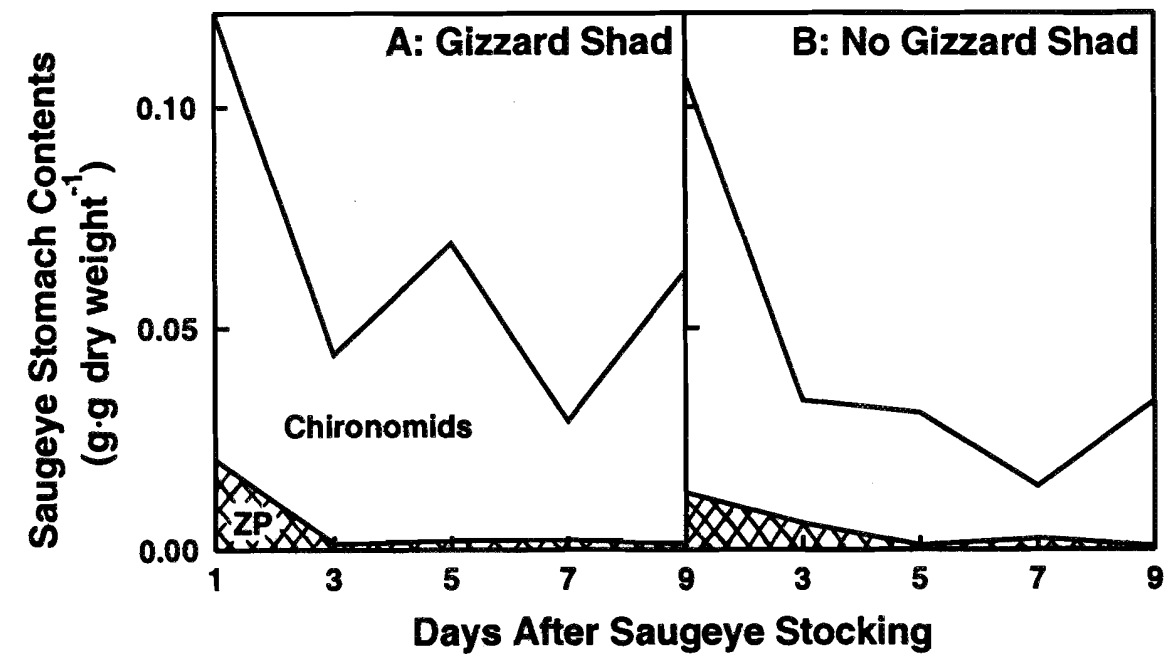

FIG. 5. Cumulative saugeye stomach contents in ponds (A) with and (B) without gizzard shad through time $(N=4$, with at least 3 saugeye analyzed per replicate) for the pond experiment done in 1992 at the Hebron State Fish Hatchery. Zooplankton, chironomid, and total stomach contents did not differ (see Table 1). ZP = zooplankton.

abundant in reservoirs to reduce the attractiveness of gizzard shad, thus delaying the switch to piscivory. Although large zooplankton (cyclopoids and Daphnia spp.) were preferred in our experiments, these taxa comprised $<<10 \%$ of the community. However, when the combined absolute densities of cyclopoids and Daphnia spp. in the ponds (19-125. $\mathrm{L}^{-1}$. pond ${ }^{-1} \cdot$ date $\left.^{-1}\right)$, and to a lesser extent in the bags $\left(0-37 \cdot \mathrm{L}^{-1} \cdot\right.$ treatment $^{-1} \cdot$ date $\left.^{-1}\right)$, and to a lesser extent in the bags $\left(0-37 \cdot L^{-1} \cdot\right.$ treatment $^{-1} \cdot$ date $\left.^{-1}\right)$, are compared with maximum densities of cyclopoids and Daphnia spp. in four Ohio reservoirs sampled in $1991\left(10-56 \cdot \mathrm{L}^{-1} \cdot\right.$ reservoir $^{-1}$; Stahl et al. 1992), preferred zooplankton abundance did not appear to be limiting in our experiments It is likely not the factor inhibiting the switch to piscivory by saugeye in Ohio reservoirs. A delayed switch also could result from spatial separation of saugeye and larval gizzard shad. YOY saugeye are collected inshore with seines and electrofishing gear (B.L. Johnson et al. 1988; Stahl et al. 1992), but their distribution within reservoirs as a whole is unknown. Although larval gizzard shad are present inshore and offshore at the water's surface (Petering and Johnson 1991; Allen and DeVries 1993), and this fish is the primary prey for stocked saugeye (B.L. Johnson et al. 1988; Stahl et al. 1992), the extent to which these fishes overlap spatially in the water column is unknown in Ohio reservoirs. B.L. Johnson et al. (1988) indicated that saugeye do consume more littoral fishes than walleye, indicating a possible spatial separation from larval gizzard shad found primarily in the open water. Just as larval fish increase activity and range with size (Miller et al. 1988), so may saugeye and gizzard shad. Thus, the switch to piscivory may be delayed by inadequate spatial overlap, being resolved when saugeye or gizzard shad increase their range through growth, as shown for walleye and yellow perch (Perca flavescens) (Lyons 1987). Quantifying the spatial distribution of YOY saugeye and gizzard shad would provide insight into this issue. Finally, a perceived delayed switch could derive from sampling bias, as has been documented for fish larvae and their zooplankton prey (Frank 1988). If spatial distribution or range of YOY saugeye increases with size, and small saugeye remain inshore, and thus do not overlap with ichthyoplankton and consume zooplankton, then inshore sampling biases our view of the time required for saugeye to switch to piscivory. To determine the presence, size distribution, and diets of saugeye offshore, trawling or other methods should be attempted.

\section{Piscivory and Growth}

Although no gizzard shad were found in stomachs of pond saugeye, saugeye probably consumed these shad. First, increased growth in the treatment with gizzard shad was not caused by differences in prey found in saugeye stomachs. Weight of food in saugeye guts did not differ with and without gizzard shad. Saugeye growth differences were likely derived from differences in prey consumption that we were unable to quantify, specifically gizzard shad consumption. Second, gizzard shad availability was the only difference in prey between treatments that could have increased saugeye growth in the treatment with gizzard shad. Although zooplankton densities were higher through time without gizzard shad, saugeye still grew fastest with gizzard shad. Densities of preferred zooplankters (cyclopoids and Daphnia spp.) and zooplankton electivity did not differ between treatments. Finally, saugeye had the ability to consume all gizzard shad and clear their guts by the time we first sampled $24 \mathrm{~h}$ after stocking. Calculations, based on YOY walleye bioenergetics (Madon and Culver 1993), show that saugeye possess the predatory and consumption potential $(0.30 \mathrm{~g}$. $\mathrm{g}^{-1} \cdot \mathrm{d}^{-1}$ for comparable YOY walleye, Culver et al. 1992) necessary to eliminate gizzard shad from the pond and their stomachs within $24 \mathrm{~h}$ (Stahl 1993). Walker and Applegate (1976) also documented the elimination of forage fish within 8 wk by stocked walleye $(N=25000,43.5 \mathrm{~mm})$ in a prairie pothole. Given this tremendous predatory potential, it is not surprising that no gizzard shad were recovered from guts. Although no formal saugeye-free control ponds existed, we believe that gizzard shad were not evading our gear because we were able to sample them in a predator-free pond that had been stocked with the same number of adult gizzard shad simultaneously with our experimental ponds. Gizzard shad in our ponds with saugeye were likely eliminated by saugeye. 
Piscivorous saugeye grew faster than zooplanktivorous/ benthivorous ones, as evidenced by both pond and bag experiments. Gizzard shad consumption drove saugeye weight gain. The influence of gizzard shad on growth was impressive - even though saugeye in ponds did not have access to gizzard shad for 10 days and grams per gram consumption was similar following gizzard shad elimination, their consumption of shad set the trajectory of the growth curve early, permitting saugeye in gizzard shad ponds to outgrow those in ponds without gizzard shad. In our bag experiment, saugeye that had access to more gizzard shad grew faster. On days 0 and 2, respectively, high-density bags had 100 and 58 gizzard shad, as compared with 20 and $<1$ gizzard shad in low-density bags. Thus, saugeye in the $100 \cdot \mathrm{m}^{-3}$ bags grew larger. As in the pond experiment, gizzard shad consumption set the trajectory of the growth curve early; saugeye in the high gizzard shad treatment were larger through the entire experiment despite gizzard shad availability and consumption being greater only through day 2 . Further, by using only the bag treatment data after which gizzard shad had been consumed, the number of gizzard shad consumed by saugeye precisely predicted saugeye growth.

Several mechanisms could account for greater growth of saugeye consuming gizzard shad as compared with those consuming zooplankton or chironomids. First, caloric densities of larval fish exceed those of chironomids or zooplankton (Cummins and Wuycheck 1971; Hewett and Johnson 1992). In addition, assimilation efficiency for fish prey is greater than that for invertebrates (Brett and Groves 1979). Therefore, weight gain by a predator from an equal biomass of each prey item should be greatest for YOY fish. Also, because saugeye are natural piscivores, they may be able to forage for fish more efficiently than for either chironomids or zooplankton. For example, on day 2 of the bag experiment, greater total biomass of prey in saugeye stomachs in the high gizzard shad treatment coincided with greater gizzard shad consumption. Greater efficiency in assimilation and consumption coupled with high caloric density of fish likely accounted for faster saugeye growth in ponds, as well as bags, with gizzard shad.

Although saugeye survival was higher in ponds without gizzard shad, differences were small $(<3 \%)$ and likely more related to our counting procedures than gizzard shad presence. In fact, in productive hatchery ponds, differences in survival based on prey availability would be unexpected over only $11 \mathrm{~d}$ (Fox 1989).

Our experiments did not determine if increased ichthyoplankton density increases saugeye growth. Clearly, when saugeye co-occurred with gizzard shad, they grew faster. However, we did not maintain constant gizzard shad densities in our experiments; therefore, these data do not provide insight into the prey density required for maximum saugeye growth. As with most animals, saugeye consumption and growth will increase with increasing prey abundance until a maximum is reached. Understanding how maximum saugeye growth is achieved given different saugeye stocking parameters (size, density, and time) and larval gizzard shad population dynamics would be useful to managers. Greater understanding can be achieved through manipulative saugeye growth experiments, field sampling of YOY saugeye and ichthyoplankton, bioenergetics models specific for 30 - to $50-\mathrm{mm}$ saugeye (sensu B.M. Johnson et al. 1988; Wahl and Stein 1991; Madon and Culver 1993), and, given the importance of size for YOY predators (Gutreuter and Anderson 1985; Miller et al. 1988; Madenjian and Carpenter 1991; Madenjian et al. 1991), an individual-based model for saugeye (sensu Madenjian and Carpenter 1991; Madenjian et al. 1991).

\section{Management Recommendations}

In nature, production of larval fish predators often coincides with production of abundant prey fish, which in turn enhances predator growth and survival (Momot et al. 1977; Adams and DeAngelis 1987; Wicker and Johnson 1987). Timing is important for stocked predators simply because prey fish must be appropriately sized (B.M. Johnson et al. 1988) at a density that can sustain high growth rates (Jester 1971; Stahl et al. 1992). Managers can control these factors by manipulating saugeye size, reservoir type, or the time of stocking in relation to prey density or size. Our experiments demonstrate that saugeye as small as $30 \mathrm{~mm}$ could consume gizzard shad at densities of $220 \cdot \mathrm{m}^{-3}$, and through this consumption increase their growth. Thus, we conclude that saugeye should be stocked as large as possible, but at least $30 \mathrm{~mm}, 1-2 \mathrm{wk}$ before peak ichthyoplankton densities, in reservoirs where gizzard shad occur.

Stocking at this size and time is advantageous for a variety of reasons. First, with this scenario, saugeye capable of consuming larval gizzard shad will have energetically favorable fish prey maximally available soon after stocking. Second, stocking saugeye slightly before the peak will allow saugeye time to increase their range to overlap spatially with, and perhaps "learn" to consume, prey fishes. Thus, any delay in switching to piscivory upon stocking occurs before peak ichthyoplankton densities, preventing saugeye from missing abundant prey, which can grow quickly out of their window of vulnerability (B.M. Johnson et al. 1988). Likewise, fast growth by gizzard shad makes stocking saugeye larger than $30-50 \mathrm{~mm}$ questionable. If reared in hatchery ponds, saugeye $>50 \mathrm{~mm}$ may not be available for stocking until YOY gizzard shad are beyond a size range vulnerable to saugeye. Finally, although peak ichthyoplankton densities cannot be precisely predicted, they occur during 2 wk in mid-May to early June in Ohio reservoirs (Stahl et al. 1992, 1993). Until methods for predicting gizzard shad hatch dates and recruitment to the pelagia have been developed, using historical data to predict peak ichthyoplankton densities should suffice. Without these data, timing of peaks can be bracketed by sampling ichthyoplankton at least weekly in spring for several years. By stocking $\geq 30-\mathrm{mm}$ saugeye $1-2 \mathrm{wk}$ prior to ichthyoplankton peaks, we believe that saugeye will be able to take advantage of larval gizzard shad, thereby improving their growth, survival, and ultimate recruitment to the fishery.

\section{Acknowledgments}

This work was funded by the Federal Aid in Sport Fish Restoration Program (F-57-R, Evaluation of Fish Management Techniques), administered jointly by the U.S. Fish and Wildlife Service and the Ohio Division of Wildlife. The Ohio Division of Wildlife provided facilities. The cooperation of Milt Austin, Randy Miller, Gary Isbell, and especially Jim Stafford, hatchery supervisor at Hebron, made our work productive and enjoyable. Field work and sample analysis were done primarily by Angela Rigsby, Elaine Scheinbart, and Gary Thiede. Technical, theoretical, and statistical advice was provided by Mary Bremigan, Dave Culver, Peter Curtis, John Dettmers, Barry Johnson, 
Mark Kershner, Ed Lewis, Chuck Madenjian, Libby Marschall, Jeff Miner, Ray Petering, and Gary Thiede.

\section{References}

ADAMS, S.M., AND D.L. DEANGELIS. 1987. Indirect effects of early bass-shad interactions on predator population structure and food web dynamics, p. 103-117. In W.C. Kerfoot and A. Sih [ed.] Predation. Direct and indirect impacts on aquatic communities. University Press of New England, Hanover, N.H.

ADAMS, S.M., R.B. MCLEAN, AND M.M. HUFFMAN. 1982. Structuring of a predator population through temperature-mediated effects on prey availability. Can. J. Fish. Aquat. Sci. 39: 1175-1184.

ALLEN, M.S., AND D.R. DEVRIES. 1993. Spatial and temporal heterogeneity of larval shad in a large impoundment. Trans. Am. Fish. Soc. 122: 1070-1079.

Bremigan, M.T., E.M. Lewis, M.B. Jones, R.A. Stein, and D.R. DeVRies. 1991. Evaluating effects of stocking threadfin shad on young-of-year crappie, bluegill, and largemouth bass in Ohio lakes. Final Report, Federal Aid in Sport Fish Restoration Project F-57-R, Study 15, Ohio Department of Natural Resources, Division of Wildlife, Columbus, Ohio.

BRETT, J.R., AND T.D.D. GRoves. 1979. Physiological energetics, p. 279-352. In W.S. Hoar, D.J. Randall, and J.R. Brett [ed.] Fish physiology. Vol. 8. Bioenergetics and growth. Academic Press, New York, N.Y.

Buisse, A.D., AND R.P. HouthuiJzen. 1992. Piscivory, growth, and sizeselective mortality of age 0 pikeperch (Stizostedion lucioperca). Can. J. Fish. Aquat. Sci. 49: 894-902.

Carlander, K.D., and P.M. Payne. 1977. Year-class abundance, population, and production of walleye (Stizostedion vitreum vitreum) in Clear Lake, Iowa, 1948-1974, with varied fry stocking rates. J. Fish. Res. Board Can. 34: 1792-1799.

Carline, R.F., R.A. Stein, AND L.M. Riley. 1986. Effects of size at stocking, season, largemouth bass predation, and forage abundance on survival of tiger muskellunge. Am. Fish. Soc. Spec. Publ. 15: 151-167.

Chesson, J. 1978. Measuring preference in selective predation. Ecology 59: 211-215.

Chesson, J. 1983. The estimation and analysis of preference and its relationship to foraging models. Ecology 64: 1297-1304.

Culver, D.A., J. Qin, S.P. Madon, AND H.A. Helal. 1992. Daphnia production techniques for rearing fingerling walleye and saugeye. Final Report, Federal Aid in Sport Fish Restoration Project F-57-R, Study 14 Ohio Department of Natural Resources, Division of Wildlife, Columbus, Ohio.

Cummins, K.W., AND J.C. WUYcheck. 1971. Caloric equivalents for investigations in ecological energetics. Mitt. Int. Ver. Theor. Angew. Limnol. 18: 1-151.

DetTMERS, J.M., AND R.A. STEIN. 1992. Food consumption by larval gizzard shad: zooplankton effects and implications for reservoir communities. Trans. Am. Fish. Soc. 121: 494-507.

DeVRies, D.R., ANd R.A. STEin. 1991. Comparison of three zooplankton samplers: a taxon-specific assessment. J. Plankton Res. 13: 53-59.

DUMONT, H.J., I. VAN DE VELDE, AND S. DUMONT. 1975. The dry weight estimate of biomass in a selection of Cladocera, Copepoda and Rotifera from the plankton, periphyton and benthos of continental waters. Oecologia 19: 75-97.

FIELDER, D.G. 1992. Evaluation of stocking walleye fry and fingerlings and factors affecting their success in lower Lake Oahe, South Dakota. N. Am. J. Fish. Manage. 12: 336-345.

FORNEY, J.L. 1976. Year-class formation in the walleye (Stizostedion vitreum vitreum) population of Oneida Lake, New York, 1966-1973. J. Fish. Res. Board Can. 33: 783-792.

Fox, M. 1989. Effect of prey density and prey size on growth and survival of juvenile walleye (Stizostedion vitreum vitreum). Can. J. Fish. Aquat. Sci. 46: 1323-1328.

FoX, M.G., J.A. KEAST, AND R.L. SWAINSON. 1989. The effect of fertilization regime on juvenile walleye growth and prey utilization in rearing ponds. Environ. Biol. Fishes 26: 129-142.

FRANK, K.T. 1988. Independent distributions of fish larvae and their prey: natural paradox or sampling artifact? Can. J. Fish. Aquat. Sci. 45 $48-5.9$.

GUTREUTER, S.J., AND R.O. ANDERSON. 1985. Importance of body size to the recruitment process in largemouth bass populations. Trans. Am. Fish. Soc. 114: 317-327

Hewert, S.S., AND B.L. JohNSON. 1992. Fish bioenergetics model 2: an upgrade of a generalized bioenergetics model of fish growth for micro- computers. University of Wisconsin, Sea Grant Institute, Technical Report WIS-SG-92-250, Madison, Wis.

HoKanSEN, K.E.F., AND G.J. LiEN. 1986. Effects of diet on fish growth and survival of larval walleyes. Prog. Fish-Cult. 48: 250-258.

JACKSON, J.J., D.W. WILLIS, AND D.G. FIELDER. 1992. Food habits of young-of-the-year walleyes in Okobojo Bay of Lake Oahe, South Dakota. J. Freshwater Ecol. 7: 329-341.

JESTER, D.B. 1971. Effects of commercial fishing, species introduction and drawdown control on fish populations in Elephant Butte Reservoir, New Mexico, p. 265-285. In G.E. Hall [ed.] Reservoir fisheries in limnology. Am. Fish. Soc. Spec. Publ. 8.

Johnson, B.L., D.L. SMITH, AND R.F. CARLINE. 1988. Habitat preferences, survival, growth, foods, and harvest of walleyes and walleye $\times$ sauger hybrids. N. Am. J. Fish. Manage. 8: 292-304.

Johnson, B.M., R.A. Stein, AND R.F. CARLine. 1988. Use of a quadrat rotenone technique and bioenergetics modeling to evaluate prey availability to stocked piscivores. Trans. Am. Fish. Soc. 117: 127-141.

Kanight, R.L., F.J. MargRaF, AND R.F. CARLine. 1984. Piscivory by walleyes and yellow perch in western Lake Erie. Trans. Am. Fish. Soc. 113: 677-693.

Li, S., AND J.A. Mathias. 1982. Causes of high mortality among cultured larval walleye. Trans. Am. Fish. Soc. 111: 710-721.

LYNCH, W.E. JR., D.L. JOHNSON, AND S.E. SCHELL. 1982. Survival, growth, and food habits of walleye $\times$ sauger hybrids (saugeye) in ponds. N. Am. J. Fish. Manage. 2: 381-387.

Lyons, J. 1987. Prey choice among piscivorous juvenile walleyes (Stizostedion vitreum). Can. J. Fish. Aquat. Sci. 44: 758-764.

MADENIIAN, C.P., AND S.R. CARPENTER. 1991. Individual-based model for growth of young-of-the-year walleye: a piece of the recruitment puzzle. Ecol. Appl. 1: 268-279.

Madenjian, C.P., B.M. Johnson, and S.R. Carpenter. 1991. Stocking strategies for fingerling walleyes: an individual-based model approach. Ecol. Appl. 1: 280-288.

MAdON, S.P., AND D.A. CUlver. 1993. Bioenergetics model for larval and juvenile walleye: an in-situ approach using experimental ponds. Trans. Am. Fish. Soc. 122: 797-813.

Mathias, J.A., AND S. Li. 1982. Feeding habits of walleye larvae and juveniles: comparative laboratory and field studies. Trans. Am. Fish. Soc. 111: 722-735.

Matthews, W.J., L.G. Hill, D.R. EdDS, J.J. Hoover, and T.G. Heger. 1988. Trophic ecology of striped bass, Morone saxatilis, in a freshwater reservoir (Lake Texoma, U.S.A.). J. Fish. Biol. 33: 273-288.

Miller, T.J., L.B. Crowder, J.A. Rice, and E.A. MarsChall. 1988. Larval size and recruitment mechanisms in fishes: toward a conceptual framework. Can. J. Fish. Aquat. Sci. 45: 1657-1670.

MittelbaCh, G.G. 1981. Foraging efficiency and body size: a study of optimal diet and habitat use by bluegills. Ecology 62: 1370-1386.

Momot, W.T., J. ERICKSON, AND F. STEvenson, 1977. Maintenance of a walleye, Stizostedion vitreum vitreum, fishery in a eutrophic river. J. Fish. Res. Board Can. 34: 1725-1733.

NoBlE, R.L. 1981. Management of forage fishes in impoundments of the southern United States. Trans. Am. Fish. Soc. 110: 738-750.

Oliver, J.D., G.F. HOLETON, AND K.E. CHUA. 1979. Overwinter mortality of fingerling smallmouth bass in relation to size, relative energy stores, and environmental temperature. Trans. Am. Fish. Soc. 108: $130-136$.

Parsons, J.W. 1971. Selective food preference of walleyes of the 1959 year class in Lake Erie. Trans. Am. Fish. Soc. 100: 474-485.

Persson, L., AND L.A. Greenberg. 1990. Optimal foraging and habitat shift in perch (Perca fluviatilis) in a resource gradient. Ecology 71: $1699-1713$

Petering, R.W., AND D.L. Johnson. 1991. Distribution of fish larvae among artificial vegetation in a diked Lake Erie wetland (Ohio, USA). Wetlands 11: 123-138.

Post, J.R., AND D.O. Evans. 1989. Size-dependent overwinter mortality of young-of-the-year yellow perch (Perca flavescens): laboratory, in situ enclosure, and field experiments. Can. J. Fish. Aquat. Sci. 46: 1958-1968.

Pyke, G.H. 1984. Optimal foraging theory: a critical review. Annu. Rev. Ecol. Syst. 15: 523-575.

Smith, L.L. JR., AND R.L. PYCHA. 1960. First year growth of the walleye (Stizostedion vitreum vitreum Mitchill), and associated factors in the Red Lakes, Minnesota. Limnol. Oceanogr. 5: 281-290.

STAHL, T.P. 1993. Exploring how larval gizzard shad density influences piscivory and growth of young-of-year saugeye (Stizostedion vitreum vitreum $\times S$. canadense). M.S. thesis, The Ohio State University, Columbus, Ohio. 72 p. 
Stahl, T.P., N.S. Donovan, R.A. Stein, ANd D.A. Culver. 1993. Evaluating saugeye stocking success in Ohio reservoirs. Annual Report, Federal Aid in Sport Fish Restoration Project F-57-R-15, Study 20, Ohio Department of Natural Resources, Division of Wildlife, Columbus, Ohio.

Stahl, T.P., R.A. Stein, AND D.A. Culver. 1992. Evaluating saugeye stocking success in Ohio reservoirs. Annual Report, Federal Aid in Sport Fish Restoration Project F-57-R-14, Study 20, Ohio Department of Natural Resources, Division of Wildlife, Columbus, Ohio.

WAHL, D.H., AND R.A. STEIN. 1988. Selective predation by three esocids: the role of prey behavior and morphology. Trans. Am. Fish. Soc. 117: $142-151$.
WAHL, D.H., AND R.A. STEIN. 1991. Food consumption and growth of three esocids: field tests of a bioenergetics model. Trans. Am. Fish. Soc. 120: $230-246$

Walker, R.E., AND R.L. Applegate. 1976. Growth, food and possible ecological effects of young-of-the-year walleyes in a South Dakota prairie pothole. Prog. Fish-Cult. 38: 217-220.

Werner, E.E., AND G.G. Mirtelbach. 1981. Optimal foraging: field tests of diet choice and habitat switching. Am. Zool. 21: 813-829.

WICKER, A.M., AND W.E. JOHNSON. 1987. Relationships among fat content, condition factor, and first-year survival of Florida largemouth bass. Trans. Am. Fish. Soc. 116: 264-271. 